УДК 811.111 '373.612.2.

DOI https://doi.org/10.26661/2414-1135-2021-84-20

\title{
АНТРОПОМОРФНЕ МЕТАФОРИЧНЕ МОДЕЛЮВАННЯ СФЕРИ-МІШЕНІ ВRЕХІТ У ПОЛІТИЧНІЙ ПУБЛІЦИСТИЦІ БОРИСА ДЖОНСОНА
}

\author{
Луценко Л. О. \\ кандидат філологічних наук, дочент, \\ дочент кафедри англійської філології \\ Криворізький державний педагогічний університет \\ просп. Гагаріна, 26, Кривий Ріг, Дніпропетровська область, Украӥна \\ orcid.org/0000-0002-8610-8471 \\ lyudmylalutsenko@gmail.com \\ Негулясва А. О. \\ студентка магістратури \\ Криворізький державний педагогічний університет \\ просп. Гагаріна, 26, Кривий Ріг, Дніпропетровська область, Украӥна \\ orcid.org/0000-0002-2094-7918 \\ allochka.neg@gmail.com
}

Ключові слова: метафора,
концептуальна метафора,
антропоморфна метафора,
метафорична модель, фрейм.

Політична журналістика є однією з визначних галузей журналістики, яка передбачає маніпулятивний вплив, віддзеркалений у використанні мовних засобів, зокрема метафор. У статті розглядається проблема антропоморфного метафоричногомоделюваннясфери-мішеніBrexit-поняття,якесталовідомим у глобальному масштабі протягом п'яти років із моменту його створення. Brexit як політичний процес і референдум, що відбувся у Великобританії у 2016 році, має такі структурні елементи: «Референдум», «Велика Британія», «виборець», «Свропейський Союз», «політичний процес» і «стратегія». Такі елементи стають об'єктом метафоричного моделювання політичної публіцистики Бориса Джонсона. Під час дослідження вдалося виявити, що найчисельнішою групою метафор є ті, які належать до сфери-джерела «Людина» й мають назву антропоморфні метафори. Теоретичні погляди Джорджа Лакоффа й Марка Джонсона на метафору, що розглядається як спосіб розуміння однієї концептуальної сфери через іншу, дають можливість авторам визначити групу фреймів антропологічних метафор, які виявляють образну складову частину концепту Brexit у публіцистиці Бориса Джонсона, зокрема: «Психологічна діяльність», «Анатомічні органи», «Культурний фон». Саме антропоморфні метафори, що асоціюються з людством, його культурою та фізичним середовищем, створюють атмосферу згуртованості й апелюють до емоційної сфери читача, його патріотизму, гідності й відчуття самоідентичності. Результати дослідження доводять, що антропологічне метафоричне моделювання є надзвичайно ефективним маніпулятивним засобом, який використовується Джонсоном із метою створення бажаної суспільно-політичної картини у свідомості читачів і впливу на їхню думку щодо Брекзиту, його позитивних аспектів і наслідків. Наше дослідження може стати підгрунтям для покращення та оптимізації технік мовленнєвого маніпулювання політичними структурами. Також результати проведеної роботи можуть знайти застосування для підвищення соціально-політичної самосвідомості індивідуумів через розвиток критичного ставлення до текстів політичної публіцистики. 


\title{
ANTHROPOMORPHIC METHAPHORICAL MODELLING \\ OF THE TARGET DOMAIN "BREXIT" \\ IN BORIS JOHNSON'S POLITICAL JOURNALISM
}

\author{
Lutsenko L. O. \\ Candidate of Philological Sciences, Associate Professor, \\ Associate Professor at the Department of English Philology \\ Kryvyi Rih State Pedagogical University \\ Haharina Ave., 26, Kryvyi Rih, Dnipropetrovsk region, Ukraine \\ orcid.org/0000-0002-8610-8471 \\ lyudmylalutsenko@gmail.com \\ Neguliaieva A. O. \\ Master Student \\ Kryvyi Rih State Pedagogical University \\ Haharina Ave., 26, Kryvyi Rih, Dnipropetrovsk region, Ukraine \\ orcid.org/0000-0002-2094-7918 \\ allochka.neg@gmail.com
}

Key words: metaphor, conceptual metaphor, anthropomorphic metaphor, metaphorical model, frame.
Political journalism constitutes one of the most prominent branches of journalism that involves manipulative influence reflected in language use, in particular, metaphors. This article addresses the problem of anthropomorphic metaphorical modeling of the target domain "Brexit" - the notion which became a global word within five years of being coined. Adopting George Lakoff and Mark Johnson's view of the metaphor seen as a way to understand one conceptual domain in terms of another conceptual domain enables the authors to identify a cluster of frames associated with anthropomorphic metaphors mirroring the image of the concept "Brexit" in political journalism authored by Boris Johnson. Brexit as a political process and referendum, which took place in The United Kingdom in 2016, has the following structural elements: "Referendum", "Great Britain", "voter", "European Union", "political process" and "strategy". Those elements become the target of the metaphorical modeling of Johnson's political journalism. During research we managed to identify that the most numerous group of metaphors are those that belong to the source-domain "Human" and called anthropomorphic metaphors. The frames of the mentioned metaphorical modeling in question are as follows: "Psychological activity", "Anatomical organs" and "Cultural background". It is anthropomorphic metaphors related to the human race, its culture and society, and its physical environment that inspire bonding atmosphere and appeal to reader's emotional sphere, patriotism, dignity and self-identification. The results of this study show that anthropomorphic metaphorical modeling is a significant and effective means of manipulative influence used by Johnson to create the desired socio-political picture in the readers' minds with a view to influencing their opinion on Brexit, its pros, delay and consequences. Our research can serve as a basis for improving and optimizing the techniques of speech manipulation of political structures. Also, the results of this work can be used to increase the socio-political self-awareness of individuals through the development of a critical attitude to the texts of political journalism. 
Постановка проблеми. В умовах сьогодення предметом жвавого наукового інтересу виявляється проблема метафоризації в політичній публіцистиці, яка, на думку Г. Солганика, $\epsilon$ «літописом сучасності, оскільки вона у всій повноті відбиває плинну історію, звернена до злободенних проблем суспільства - політичних, соціальних, побутових, філософських та інших» [2, с. 202].

Результати студіювання метафори на мовному рівні в політичній публіцистиці репрезентовано в ряді робот вітчизняних вчених (I. Брага, Х. Дацишин, Л. Павлюк, О. Сербенська, І. Філатенко, О. Чадюк, Г. Яворська й інші), а також дослідників пострадянського простору (А. Баранов, В. Володіна, Ю. Караулов, В. Костомаров, Г. Солганик, А. Чудінов та інші).

Розвиток когнітивної наукової парадигми у XX ст. вибудовує підгрунтя для дослідження механізмів застосування метафор у політичній лінгвістиці як дієвої когнітивної моделі світу, що відбиває принципи мислення та $\epsilon$ засобом формування та визначення напрямів діяльності людства, світогляду.

Завдяки започаткуванню лінгвістами Дж. Лакофф, М. Джонсоном, Е. Маккормаком, Р. Гаскеллом, А. Барановим та іншими наукової традиції інтерпретації метафори як способу пізнання світу й засобу вторинної номінації явищ дійсності з'являється можливість досліджувати політичну публіцистику в перспективі когнітивної лінгвістики, що засвідчує актуальність нашої роботи.

Отже, мета наукової розвідки - схарактеризувати специфіку метафоричного моделювання сфери-мішені Brexit у сучасному англомовному публіцистичному тексті на основі аналізу статей Бориса Джонсона, що зумовлює розв'язання таких завдань: викласти теоретичне підгрунтя інтерпретації поняття метафори в перспективі досліджень із когнітивної лінгвістики; дослідити особливості функціонування антропоморфних метафор, що віддзеркалюють образну складову частину сфери-мішені Brexit, зокрема в аспекті маніпулятивного впливу на читача.

Об'єктом дослідження є особливості метафоричного моделювання в текстах публіцистичних статей Бориса Джонсона, опублікованих у виданні “The Daily Telegraph” протягом 2018-2019 років, а також їхній маніпулятивний потенціал.

Предметом дослідження $\epsilon$ антропоморфна метафора сфери-мішені Brexit у політичній публіцистиці Б. Джонсона.

Виклад основного матеріалу дослідження 3 обгрунтуванням отриманих наукових результатів. Стрижневою парадигмою сьогодення $€$ когнітивна теорія метафори, в основу якої покладено перехід до знань, що спираються на процеси пізнання, сприйняття, мислення та віддзеркалюються у свідомості індивідуумів.
Засновниками когнітивного підходу в розумінні механізму метафори вважають Дж. Лакофф і М. Джонсон, які зазначають, що «метафоризація грунтується на взаємодії двох структур знань когнітивної сфери (структури) «джерела» (source domain) і когнітивної сфери «мішені» (target domain). У процесі метафоризації деякі ділянки «мішені» структуруються за образом «джерела», і відбувається так звана «метафорична проєкція» (metaphorical mapping) або «когнітивне відбиття» (cognitive mapping)» [5, c. 9].

Дослідник А. Чудінов запропонував схематичне позначення метафоричної моделі за допомогою формули «X - це Y» [3, с. 131]. Співвідношення між складниками зазначеного виразу не $\epsilon$ прямим ототожненням. Такий взаємозв'язок проявляється як подібність: «Х подібний до Ү». За зазначеною формулою система фреймів (слотів, концептів) однієї ментальної сфери (сфери-джерела) виступає основою для моделювання ментальної системи іншої сфери (сфери-мішені). Завдяки когнітивному моделюванню у сфері-мішені переважно зберігається як побудова вихідної сфери, так і емоційна складова частина, характерна для концептів сфери-джерела, що породжує потужне поле впливу на емоційно-вольову сферу.

У межах когнітивноїтеорії метафорична модель містить у собі комплекс компонентів, серед яких А. Чудінов виокремлює такі: вихідна поняттєва галузь - первинна сфера-джерело, що репрезентована словами, які входять до моделі в первинному значенні; нова поняттєва галузь або вторинна семантична сфера (сфера-мішень) зі словами, що охоплюють модель у вторинному значенні; семантичний компонент, який виступає зв'язком між сферою-джерелом і сферою-мішенню; фрейми моделі, кожен з яких виступає фрагментом мовної картини світу й структурує відповідну поняттєву область (семантичну сферу); типові слоти, що $є$ складовими частинами фрейму й містять елементи певної ситуації фрейму; продуктивність моделі; прагматичний потенціал моделі, іншими словами, здатність метафор здійснювати вплив на свідомість адресата [3, с. 131-133].

Як бачимо, когнітивна метафорична модель $\epsilon$ не тільки засобом самопізнання та пізнання навколишнього світу, яка структурує поняття однієї сфери за допомогою термінів інших сфер. Когнітивній метафоричній моделі також притаманний гносеологічний характер, що уможливлює іiі здатність виступати потужним засобом здійснення маніпуляції свідомістю індивідуумів. На думку О. Михальової, «<..> за допомогою влучних метафоричних моделей маніпулятор здатен побудувати вигідну для нього картину світу у свідомості слухачів» [1, с. 123]. 
Одним із найдієвіших засобів здійснення маніпулятивного мовленнєвого впливу є використання антропоморфних метафоричних моделей у політичній публіцистиці Бориса Джонсона - видатної постаті Великобританії, британського політика, колишнього журналіста й чинного прем'єр-міністра, який на певному етапі своєї кар'єри активно займається публіцистичною діяльністю. Зокрема, протягом 1994-1999 років він обіймає посаду заступника головного редактора "The Daily Telegraph", із 1998 року співпрацює з $B B C$ у програмі "Have I Got News for You", iз 2000 року по 2005 рік працює головним редактором тижневика "The Spectator”. Напередодні обрання прем'єр-міністром Великобританії (2018-2019 роки) Б. Джонсон веде власну щотижневу політичну колонку в "The Daily Telegraph".

Протягом досить довгого часу найактуальнішою та найболючішою для Великої Британії виявляється тема виходу з Свропейського Союзу, який отримав специфічну назву Brexit. 32016 року, за даними $B B C$-news, в Оксфордському словнику англійської мови з'являється означення поняття Brexit: "the (proposed) withdrawal of the United Kingdom from the European Union, and the political process associated with it. Sometimes used specifically with reference to the referendum held in the UK on 23rd June 2016, in which a majority of voters favoured withdrawal from the $E U$ ” [6]. Як бачимо, сфера-мішень Brexit у словниковій літературі представлена такими поняттєвими елементами, як «референдум», «Великобританія», «виборець», «Європейський союз», «політичний процес», «стратегія», чий кластер розглядається в аспекті метафоризації в статті.

Дослідження публіцистики Б. Джонсона дає можливість ідентифікувати низку метафоричних моделей сфери-мішені Brexit, особливо антропоморфних. Так, антропоморфна метафорична модель сфери-мішені Brexit представлена через взаємодію двох людей - сторін, які не можуть домовитися та перебувають у процесі довгострокової конфронтації, причому їх взаємовідносини відбуваються на психологічному рівні. Фрейм «Психічна діяльність» ідентифіковано в таких антропоморфних метафорах:

(1) We need to recognize that in many ways Brexit was a cry for attention from places that have felt neglected, and that are full of potential if only they were given a chance [4];

(2) If there was one lesson from that referendum in 2016, it was that too much of the country feels unable to take part in the national success [4];

(3) And yet it was one of the lessons of the Brexit referendum that there are parts of the country that feel left behind [4];

(4) UK should have the peace of mind and confidence [4];
(5) If this One Nation Conservative government is lucky enough to be returned to office next month we will have an infrastructure revolution for this country [4] ;

(6) And because we are the only party that understands the balance and symmetry at the heart of the UK economy [4].

У процесі такого метафоричного моделювання Brexit представлений як дещо бажане й цінне, подія, що могло б змінити на краще долю всієї нації, «врятувати» ії від негативних наслідків його затримки. У такий спосіб автор підвищує цінність процесу виходу з $\mathrm{CC}$, акцентує читача на необхідності пришвидшення такого політичного процесу. Нація британців і країна в цілому в процесі такого метафоричного моделювання окреслюється як така, що втратила віру, поневолена Європейським союзом і повинна спонукати уряд на рішучі дії, «зібрати всю свою мужність і показати характер» для здійснення бажаного виходу Великобританії зі складу Європейського союзу. Автор застосовує позитивно забарвлене метафоричне моделювання для створення образу консервативної партії та переконує читачів, що саме партія, яку він очолює, здатна здійснити бажаний Brexit і звільнити країну від влади Європейського союзу.

Таким чином, у фреймі «Психічна діяльність» Brexit i його складові поняттєві елементи представлені через широкий спектр психологічних процесів, які притаманні людині: емоції, відчуття, прояви рис характеру і волі. Таке антропоморфне метафоричне моделювання має високий маніпулятивний потенціал, надає емоційності й глибини тексту й формує в читачів відповідні конотативні відтінки.

Поширеним видом антропоморфного моделювання $\epsilon$ також фрейм, в якому репрезентація сфери-мішені Brexit відбувається через категорію «Анатомічні органи». Наприклад:

(7) Whatever we do, and no matter how much we struggle, we will feel the teeth of the trap biting deeper into our flesh [4];

(8) Sometimes you need to deploy the old sidestep; sometimes you palm them off with another member of your team [4];

(9) That is because the very purpose of the Act is to weaken the UK's negotiating hand in Brussels, and to give crucial cards to the EU [4];

(10) Our destiny will be in our own hands, and that will be immensely healthy [4].

У фреймі «Анатомічні органи», широко представленому в публіцистиці Джонсона, є метафоричне моделювання 3 компонентом heart. Наприклад:

(11) But as Helmut Kohl and others made clear, the real purpose was political - to knit the peoples of the EU together in a union of hearts and minds [4]; 
(12) There were lifelong Eurosceptics who decided at the last moment to remain; and a great many, in my view, whose heart said leave, but whose resolve was finally shaken by the warnings of the Government, the $B B C$, Barack Obama, the Archbishop of Canterbury, the $C B I$, every major political party and much of the media [4].

Використання компоненту heart підвищує значущість політичних подій та урядовців, додає їм морального аспекту й широкого спектра конотативних варіантів.

Численними в публіцистиці Бориса Джонсона $\epsilon$ приклади моделювання фрейму «Анатомічні органи» сфери-мішені Brexit за допомогою компоненту face:

(13) The country that possesses these essential building blocks of liberalism will succeed; the country without them will - eventually - face disaster [4];

(14) It is time to unite the Tories, get Brexit done, turn to face the real foe - and believe in what the UK can do [4];

(15) Sometimes in politics you can face a dilemma so painful that the best thing can be to lay it out before your own constituency association, and ask for their advice;

(16) If we agree this deal - and unless we have a radical change in our approach to the negotiations we face an even greater humiliation in the second phase [4];

(17) This is such a stonking, stinking, steaming lie that it is amazing that anyone in government can propose it with a straight face [4];

(18) Jeremy Corbyn would not only be an economic nightmare; he is the biggest threat to freedom that this country has faced for decades [4].

Як бачимо, Борис Джонсон ідентифікує Brexit 3 індивідуумом не тільки на рівні фізичного тіла, цілісного організму й окремих його частин. Репрезентація сфери-мішені Brexit у такий спосіб утворює тісний зв'язок із читачем і на підсвідомому рівні впливає на його здатність критично оцінювати політичні процеси й події.

Окремим фреймом антропоморфного моделювання сфери-мішені Brexit виокремлюємо «Культурний фон». За його допомогою автор проводить проєкції культурного життя та традицій, історичних фактів і звичаїв на сферу-мішень Brexit. Ocoбливо яскравим прикладом метафоричного моделювання сфери-мішені Brexit у рамках фрейму $\epsilon$ метафори, що розгортаються на рівні тексту. Наприклад:

(19) It was meant to be the week when church bells were rung, coins struck, stamps issued and bonfires lit to send beacons of freedom from hilltop to hilltop [4];

(20) This was the Friday when Charles Moore's retainers were meant to be weaving through the moonlit lanes of Sussex, half blind with scrumpy, singing Brexit shanties at the tops of their voices and beating the hedgerows with staves [4].

Уживання такого виду метафор сприяє зануренню читача в навмисно створену автором атмосферу, навіює певний настрій. Окреслене метафоричне моделювання має високий рівень впливу завдяки своєму емоційно-експресивному навантаженню. Борис Джонсон використовує культурно-історичний здобуток Великої Британії для моделювання сфери-мішені Brexit iз прагматичною метою: звернутися до свідомості читачів, до їх почуття патріотизму, гідності й самоідентифікації та вплинути на їх думку, сформувати бажане негативне ставлення до затримки Brexit та уряду, який не сприяє його здійсненню. Зазначений фрейм має досить високий маніпулятивний потенціал, адже британці - це нація з високим рівнем національної самосвідомості й шанобливим ставленням до багатої культури й історії Великої Британії.

Висновки й перспективи подальших розробок у напрямі. Отже, у статті було виокремлено декілька фреймів антропоморфного метафоричного моделювання сфери-мішені Brexit, а саме: «Психічна діяльність», «Анатомічні органи», «Культурний фон». За допомогою такого моделювання відбувається ототожнення "Brexit" із психічними процесами, притаманними індивідууму. Автор звертається до емоційно-вольової сфери, почуттів та інших процесів людської життєдіяльності. Уживання Б. Джонсоном влучних антропоморфних метафор із метою репрезентації сфери-мішені Brexit дозволяє автору здійснювати бажаний маніпулятивний вплив, корегувати поведінку індивідуумів і спонукати потенційний електорат на дієві рішення. Перспективою подальшого дослідження вважаємо студіювання інших когнітивних моделей метафоризації зазначеного концепту.

\section{ЛІТЕРАТУРА}

1. Михалева О.Н. Политический дискурс как сфера реализации манипулятивного воздействия : дисс. ... канд. филол. наук : 10.02.01. Иркутск, 2004. 289 с.

2. Солганик Г.Я. Стилистика текста : Учебное пособие. 2-е издание. Москва : Флинта : Наука, 2000. 256 с.

3. Чудинов А.П. Политическая лингвистика : учебное пособие. Москва : Флинта : Наука, 2006. $256 \mathrm{c.}$

4. Boris on Brexit and the EU. URL: https:// www.telegraph.co.uk/boris-on-brexit-eu/ (дата звернення: 16.08.2021).

5. Lakoff G. Metaphors we live by. Chicago : University of Chicago Press, 2003. $191 \mathrm{p}$.

6. Oxford English dictionary. URL: https:// www.oed.com/ (дата звернення: 05.08.2021). 


\section{REFERENCES}

1. Mikhaleva, O.N. (2004) Politicheskiy diskurs kak sfera realizatsii manipulyativnogo vozdeystviya [Political discourse as a sphere of realization of manipulative influence] (PhD Thesis), Irkutsk : Science.

2. Solganik, G.Ya. (2000) Stilistika teksta : uchebnoe posobie [Stylistics of the text: Textbook]. Moscow : Flint: Science.
3. Chudinov, A.P. (2006) Politicheskaya lingvistika : uchebnoe posobie. [Political linguistics]. Moscow : Flinta : Nauka.

4. Boris on Brexit and the EU. URL: https: //www. telegraph.co.uk/boris-on-brexit-eu/ (16.08.2021).

5. Lakoff, G. Metaphors we live by. Chicago: University of Chicago Press, 2003. 191 p.

6. Oxford English dictionary. URL: https:// www.oed.com/ (05.08.2021). 